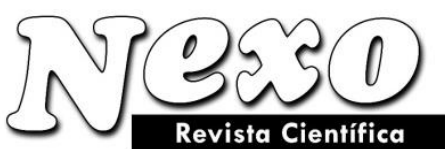

Vol. 33, No. 02, pp. 423-430/Diciembre 2020

\title{
Investigation on the direct shoot regeneration in date palm CV.Pyarum and possible genetics changes in induced shoots
}

\section{Investigación sobre la regeneración directa de brotes en la palmera datilera CV.Pyarum y posibles cambios genéticos en brotes inducidos}

\author{
Mansoor Heidarpoor ${ }^{1}$, Mansoor Kalantar ${ }^{1, *}$, Mahmoud Khosroshaheli ${ }^{2}$, Eslam Majidi Hervan ${ }^{2}$ \\ ${ }^{1}$ Department of Plant Breeding, Yazd Branch, Islamic Azad University, Yazd, Iran \\ ${ }^{2}$ Department of Biotechnology and Plant Breeding, Science and Research Branch, Islamic Azad \\ University, Tehran, Iran
}

*Corresponding author email: mkalantar2018@ gmail.com

(recibido/received: 30-July-2020; aceptado/accepted: 14-August-2020)

\begin{abstract}
The palm (Phoenix Dactylifera) is one of important trees, and is economically important in south of Iran. Date palm is propagated by the offshoots, number of which is limited. Therefore, adult Date palms produce shoot tips and axillary shoot meristems through the use of a tissue culture. This study was conducted to perform in -vitro tissue culture direct shoot regeneration and determine the best combination of plant regulators and other conditions. To achieve organogenesis and multiplication directly from shoot tips and axillary shoot meristems of Date palm (Phoenix Dactylifera L. Var Pyarum) was used without callus formation. Direct regeneration of vegetative buds minimizes the risk of somaclonal variation among plant regenerates. Results revealed that MS medium supplemented with $4 \mathrm{mg} / \mathrm{l}$ of kinetin and $3 \mathrm{mg} / \mathrm{l}$ of IAA or $2 \mathrm{mg} / \mathrm{l}$ of BA and $4 \mathrm{mg} / \mathrm{l}$ of NAA was the best formation from shoot tip after 16-20 weeks. Subculture per month was evaluated at following conditions: temperature for growth of $27 \pm 1^{\circ} \mathrm{C}$ during the lighted period and $22 \pm 1^{\circ} \mathrm{C}$ during the dark period.
\end{abstract}

Keywords: In -Vitro, Regeneration, Plant Growth Regulators, Pyarum.

\section{RESUMEN}

La palma (Phoenix Dactylifera) es uno de los árboles importantes y es económicamente importante en el sur de Irán. La palmera datilera se propaga por las ramificaciones, cuyo número es limitado. Por lo tanto, las palmas datileras adultas producen puntas de brotes y meristemas de brotes axilares mediante el uso de un cultivo de tejidos. Este estudio se realizó para realizar un cultivo de tejidos in vitro, regeneración directa de brotes y determinar la mejor combinación de reguladores de plantas y otras condiciones. Para lograr la organogénesis y la multiplicación directamente de las puntas de los brotes y meristemas de los 
brotes axilares de la palmera datilera (Phoenix Dactylifera L. Var Pyarum) se utilizó sin formación de callos. La regeneración directa de cogollos vegetativos minimiza el riesgo de variación somaclonal entre plantas regeneradas. Los resultados revelaron que el medio MS suplementado con $4 \mathrm{mg} / 1$ de kinetina y 3 mg / 1 de IAA o $2 \mathrm{mg} / 1$ de BA y $4 \mathrm{mg} / 1$ de NAA fue la mejor formación a partir de la punta del brote después de 16-20 semanas. Se evaluó el subcultivo por mes en las siguientes condiciones: temperatura de crecimiento de $27 \pm 1^{\circ} \mathrm{C}$ durante el período iluminado y $22 \pm 1^{\circ} \mathrm{C}$ durante el período oscuro.

Palabras clave: In-Vitro, Regeneración, Reguladores del Crecimiento Vegetal, Pyarum.

\section{INTRODUCCIÓN}

Date palm (Phoenix Dactyliferous L, $2 \mathrm{n}=36$ ) is a dioecious perennial monocotyledon, and cultivation of highly heterozygous Date palm also is one of the most economically important activities in the zones of the Middle East and North Africa region, as in this region, 62 million of the 105 million Date palm trees worldwide grow on an area of over one million ha $(1,264,611$ ha). It also has special significance due to its distinguished economic, nutritional, esthetic, historic, and social values. It is propagated traditionally by offshoots or seeds, on the other hand, because of heterozygosity, the plantlets produced from seeds are not identical, and are less in quality than the mother plant, and are approximately 50\% male. Propagation by offshoots is the best approach, but there is not sufficient number of offshoots. To meet this need, one should establish a new garden, because number of offshoots produced from each tree is limited during the life of the palm. The seed propagation method is the oldest means of Date palm propagation. Date palms produce shoots from axillary shoot meristems and inflorescences from floral meristems (Sudhersan, AboEl-Nil, \& Al-Baiz, 1993).

The use of offshoots for Date palm propagation is the most conventional vegetative technique at the farm level (Al-Khateeb, 2006). Plant tissue culture techniques have been used to clone a wide range of economically important palms. Using these techniques, Date palms can be micro propagated either by somatic embryogenesis in which embryos are produced from embryogenic calluses and then are germinated to form complete plantlets (McCubbin, Zaid, \& Van Stade, 2004) or through organogenesis in which plantlets are produced from the multiplied buds without passing through the callus stage (AlKhateeb, 2006).

\section{MATERIALS AND METHODS}

Apical, lateral buds and other segments of leaves from young offshoot of Palm Dactylifera L. var pyarum, coming from Hormozgan were excised as explant source. Suitable offshoots for in -vitro culture had an average weight of 2.5-6 kg (Beauchesne, Zaid, \& Rhiss, 1986; Krueger, 2001), 3-5 years old, 60-80 cm high or bearing 8-12 leaves (Chao \& Krueger, 2007). Once removed, the offshoots were cleaned off from the soil, then all the roots and leaves were severely cut back before transportation to the lab. The best time period for starting in -vitro culture from offshoots is between end of Date fruit harvest and start of the next flowering stage (Beauchesne et al., 1986) (Figure 1: A, B, C, D, and E). 


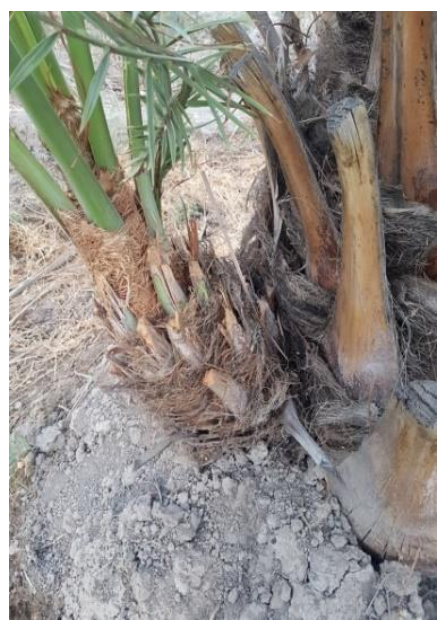

A

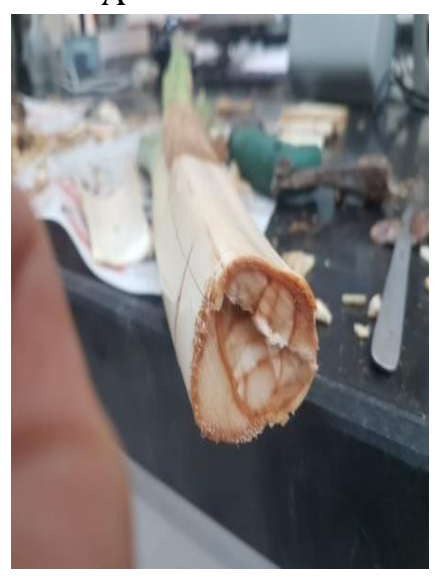

D

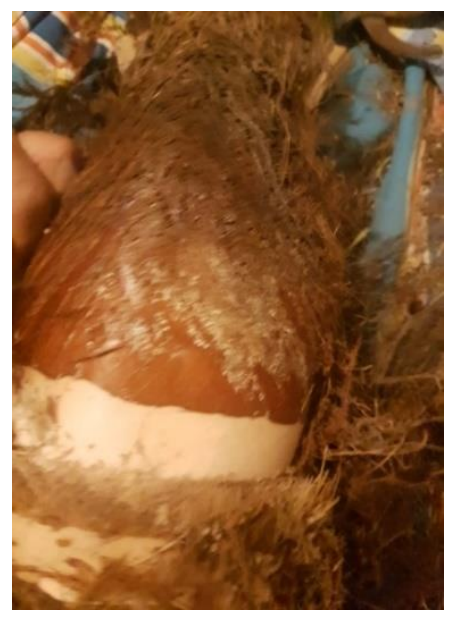

B

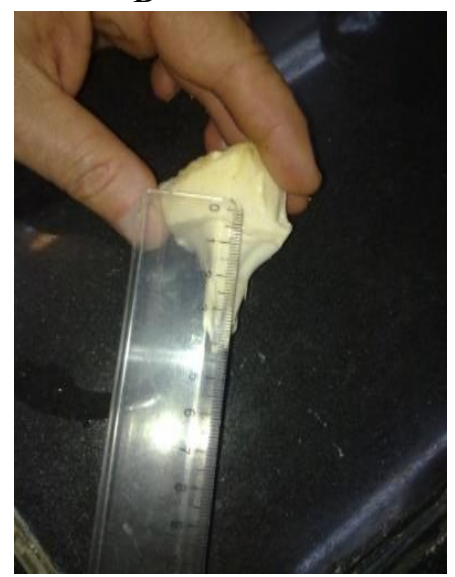

E

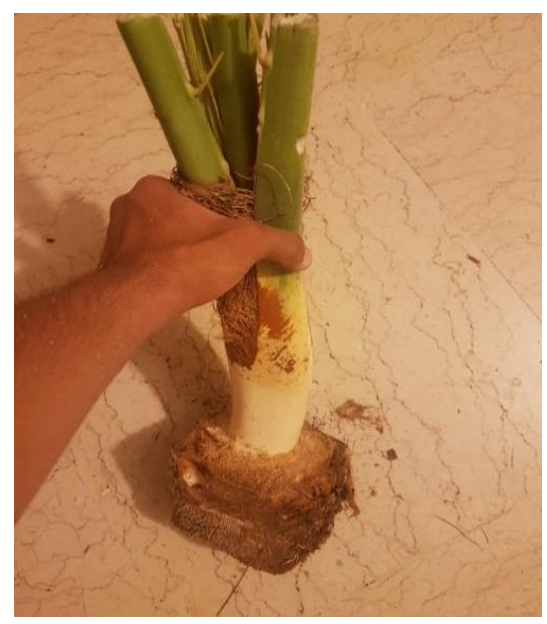

C

Figure 1: A) date palm with offshoot $\mathrm{CV}$ pyarum in garden; B) Date palm offshoot dissecting; C) Primary leaves offshoot separation; D) Shoot tip before excision; E) Shoot tip after excision.

Offshoot preparation was done using a sharp knife by gradually removing outer leaves and fibrous tissues (one by one) at their bases until reaching the shoot tip zone. Careful handling is recommended to avoid damage to the brittle meristematic region. Then, the shoot tip was excised by cutting a circle around base of the cylindrical shoot tip at an angle of $45^{\circ}$. Ultimate size of the excised shoot tip should be about 3-4 $\mathrm{cm}$ in width and $6-8 \mathrm{~cm}$ in length. A sheathing leaf base enclosing very young leaves of the heart of the offshoot should be left in place to protect it from disinfection solutions. A chain saw can also be used to make extraction of the shoot tip easier. Once removed, the shoot tip was transferred to an antioxidant solution containing $100 \mathrm{mg}$ of ascorbic acid and $150 \mathrm{mg}$ of citric acid to avoid tissue browning due to the phenolic compounds. The excised shoot tips were disinfected according to the following steps: (1) the shoot tips were cleaned with distilled water to remove any organic debris; (2) were soaked in a fungicide solution (benomyl, mancozeb) for 10-15 min; (3) were rinsed three times with sterile distilled water; (4) and were soaked again for $20 \mathrm{~min}$ in a commercial Clorox solution (sodium hypochlorite) supplemented with $0.3 \mathrm{~g} / \mathrm{l}$ of potassium permanganate; (5) and then were rinsed three times with sterile distilled water under aseptic conditions (Abahmane, 2011). Other disinfection protocols are available and can be used according to the studies by (Al-Khayri, 2018; Beauchesne et al., 1986; Krueger, 2001; Saker, Bekheet, Taha, Fahmy, \& Moursy, 2000).

After sterilization, the root tip was dissected to extract the cultured explants. Using scalpel and forceps, young leaves surrounding the apical dome were gradually removed. The explants consisted of bottom of the excised leaves. It is difficult to separate very young leaves closely surrounding the apical dome, thus the entire shoot tip was cut into 4-6 pieces and was transferred to a culture medium. At the axils of young 
leaves, axillary buds can be found, and are suitable as explants. To avoid desiccation, explants must be immediately transferred to a prepared culture medium. In general, an average of 15-25 explants can be extracted from each offshoots shoot tip. After transferring into culture media, explants were incubated for 3-6 months in the dark to enhance bud initiation and to prevent oxidation of phenolic compounds, occurring under light conditions. Explants were transferred to fresh media each month. After initiation, shoots were transferred to the lighted conditions with a photoperiod of $16 \mathrm{~h}$. Air temperature in the growth chamber was maintained at $27 \pm 1^{\circ} \mathrm{C}$ during the lighted period and $22 \pm 1{ }^{\circ} \mathrm{C}$ during the dark period (Abahmane, 2011). Generally, a basal medium of Murashige and Skoog (1962) (MS) inorganic salts was used for micropropagation of Date palm (Murashige \& Skoog, 1962). Based on the multiplication stage, it can be used at full strength or diluted usually to half strength due to its high level of mainly ammonium salts. A formulation for macro elements proposed by Beauchesne et al. (1986) was used primarily at initiation step (Beauchesne et al., 1986). In addition to the previously-mentioned mineral salts, the following chemicals are usually added to the culture medium, especially NaH2PO4 (170 mg/l), myoinositol $(100 \mathrm{mg} / \mathrm{l})$, adenine $(30 \mathrm{mg} / \mathrm{l})$, glutamine $(200 \mathrm{mg} / \mathrm{l})$, nicotinic acid $(1 \mathrm{mg} / \mathrm{l})$, pyridoxine-HCl $(1$ $\mathrm{mg} / \mathrm{l})$, Biotin $(1 \mathrm{mg} / \mathrm{l})$, calcium pantothenate $(1 \mathrm{mg} / \mathrm{l})$, sucrose $(30 \mathrm{~g} / \mathrm{l})$, agar $(6.8 \mathrm{~g} / \mathrm{l})$ (Al Khateeb 2006; Beauchesne 1983), and activated charcoal ( $3 \mathrm{gr} / \mathrm{l})$. Plant growth regulators were added according to the multiplication stage (IAA3mg/l+ kinetin $4 \mathrm{mg} / \mathrm{l}$ or BA2mg/l +NAA4mg/l) (Table 1).

Table 1. Plant growth regulators used in initiation stage.

\begin{tabular}{l|l|l|l|l}
\hline Treatment & IAA 3mg & Kinetin 4mg & BA 2mg & NAA 4mg \\
\hline$A$ & + & + & - & - \\
\hline$B$ & & & & \\
\hline
\end{tabular}

The culture media were dispensed in test tubes or in culture jars $(250 \mathrm{ml}$ flasks, $170 \mathrm{ml}$ baby food jars or magenta containers) at $50 \mathrm{ml}$. Then, the media were autoclaved at $121^{\circ} \mathrm{C}$ and under 1 bar pressure for $15-$ $30 \mathrm{~min}$ according to the culture medium volume in the containers. Activated charcoal is among the compounds widely used to avoid tissue browning. However, a great amount of added growth regulators is also absorbed by activated charcoal, and this is why high hormone concentrations are commonly used with this adsorbent (50-100 mg/l coupled with $3 \mathrm{~g} / \mathrm{l}$ of activated charcoal) (Figure 2: A, B, C, D, E, F). 


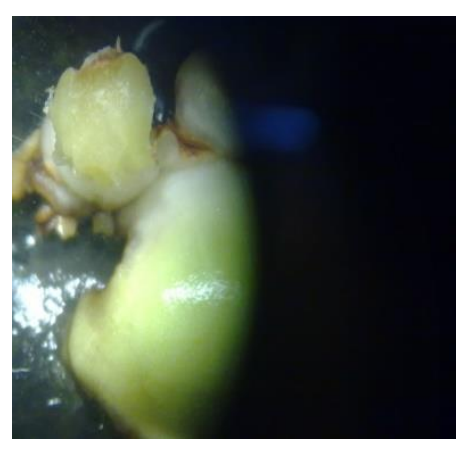

A

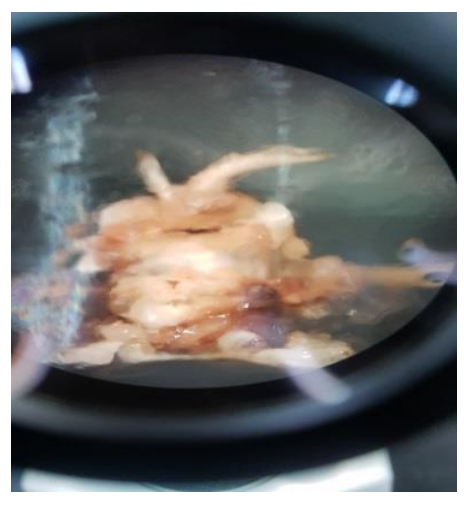

$\mathrm{D}$

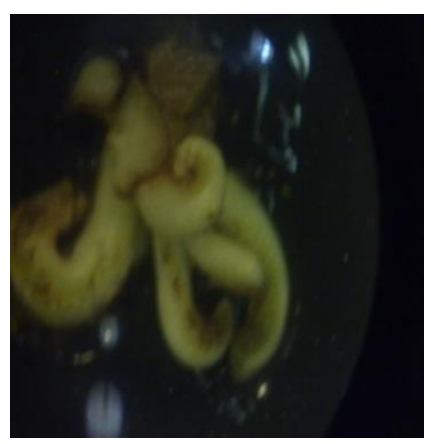

B

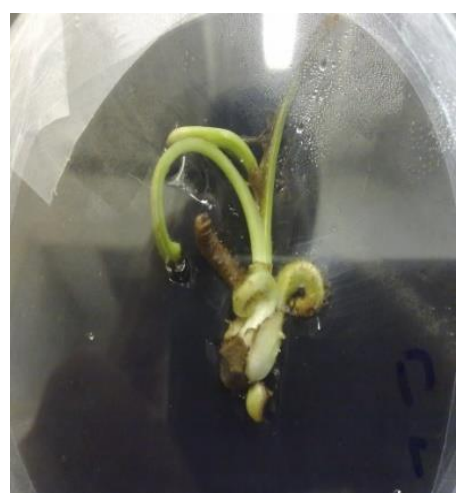

$\mathrm{E}$

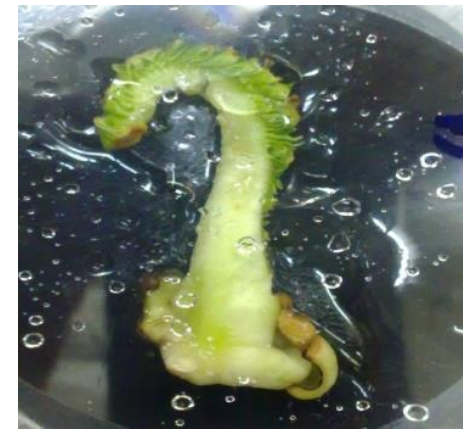

C

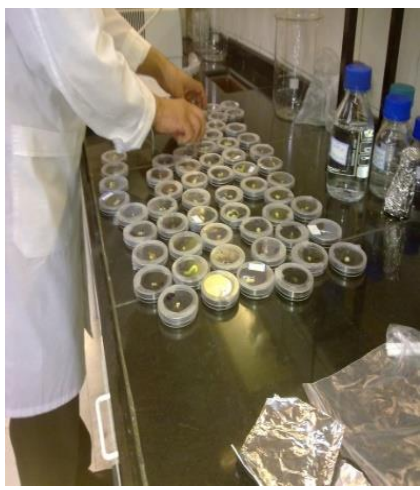

$\mathrm{F}$

Figure 2: A) morphogenic responses of regulators; B) Shoot-tip after fourteen weeks on the medium MS; C) Direct shoot proliferation on the medium MS; D) Quarter of apical meristem (explant) after Twelve weeks on the medium MS; E) Proliferated shoots; F) explants in plate.

\section{RESULTS AND DISCUSSION}

\section{Comparing the Best Time to Disinfect Small Samples}

To find the best method for disinfection of micro-samples, the samples were disinfected with hypo sodium chloride $20 \%$ and 8 drops of Tween 20 three times for 10-15 and 20 minutes, respectively. They are safe for 32 minutes after treatment. On the other hand, at 25 minutes, sodium hypochlorite $(20 \%)$ eliminates surface contamination (fungal contamination), and at least $10 \%$ of minor side-infected samples were contaminated. The fungus finally got 15 minutes of the best time for surface disinfection. These results are consistent with results obtained in the study by Al Kaabi et al (2001) in Iraq (Al Kaabi, Rhiss, \& Hassan, 2001). After removing the leaves and Date palms, the end portion of the cushion is about $10-15 \mathrm{~cm}$ to the end. The meristem area has a number of lateral buds that can withstand when they become full of energy received from sunlight. In each series of leaflets around the detached ends of the meristem, there was a lateral bud, which is usually small towards the end of the meristem and they become smaller. Of course, there were also exceptions, including first small buds, but in the middle, large lateral buds were then tiny at the end. Meanwhile, naturally sprouts on the sides of the upper meristem would be smaller as they approached the lateral region. Cultivation of lateral buds, both near and far from the terminal meristem is different. No change such as emergence of bulge, callus, and enlargement was observed after 32 weeks. 
In this research, four hormonal treatments were used according to Table 1. Various ratios of IAA, KI, BA, NAA, and 2IP were used. No effects were observed as a result of administrating the above treatments on increase percentage in the explant embryogenesis and

regeneration of the test. As shown in Table 2, none of the treatments had any effect within the first month, and after the second sub -culture, the effects of the treatments were observed, so that the best treatment effect was found to be different on different samples. The effect of auxin on embryogenesis was the best effect of hormone on embryogenesis of treatment A. The best effect of hormone treatment on regeneration of treatment D was as follows: the amount of Cytokinin was higher than auxin levels, and consequently Cytokinin effects were dominant on the regeneration than auxin effects (Table 2,3).

Table 2. Shoot formation of date palm on MS media containing various Growth Regulators

\begin{tabular}{c|c|c|c|c|c}
\hline Treatment & IAA (mg/l) & $\mathrm{Ki}(\mathrm{mg} / \mathrm{l})$ & BA (mg/l) & NAA (mg/l) & 2ip (mg/l) \\
\hline A & 5 & 4 & - & - & - \\
\hline B & - & - & 3 & 4 & 2 \\
\hline C & 2 & 4 & - & - & - \\
\hline D & - & - & 3 & 3 & 4 \\
\hline
\end{tabular}

Table 3. Effect of growth regulators on the induction of meristems regeneration

\begin{tabular}{|c|c|c|c|c|}
\hline Sub culture time & Treatment & Increase in size percent & $\begin{array}{l}\text { Embryo } \\
\text { number }\end{array}$ & Regeneration percent \\
\hline \multirow{4}{*}{1} & $\mathrm{~A}$ & 0 & 0 & 0 \\
\hline & B & 0 & 0 & 0 \\
\hline & $\mathrm{C}$ & 0 & 0 & 0 \\
\hline & $\mathrm{D}$ & 0 & 0 & 0 \\
\hline \multirow{4}{*}{2} & $\mathrm{~A}$ & 8 & 0 & 0 \\
\hline & $\mathrm{B}$ & 6 & 0 & 0 \\
\hline & $\mathrm{C}$ & 9 & 0 & 0 \\
\hline & $\mathrm{D}$ & 8 & 0 & 0 \\
\hline \multirow{4}{*}{3} & $\mathrm{~A}$ & 7 & 0 & 0 \\
\hline & B & 8 & 0 & 0 \\
\hline & $\mathrm{C}$ & 9 & 0 & 0 \\
\hline & D & 11 & 0 & 0 \\
\hline \multirow{4}{*}{4} & $\mathrm{~A}$ & 10 & 5 & 6 \\
\hline & B & 8 & 1 & 0 \\
\hline & $\mathrm{C}$ & 10 & 0 & 3 \\
\hline & D & 12 & 2 & 8 \\
\hline \multirow{4}{*}{5} & $\mathrm{~A}$ & 10 & 7 & 9 \\
\hline & B & 12 & 2 & 2 \\
\hline & $\mathrm{C}$ & 6 & 1 & 3 \\
\hline & D & 8 & 5 & 12 \\
\hline \multirow{4}{*}{6} & A & 11 & 15 & 11 \\
\hline & $B$ & 9 & 3 & 5 \\
\hline & C & 11 & 2 & 6 \\
\hline & D & 12 & 7 & 14 \\
\hline
\end{tabular}




\section{Effect of Hormone-A On Thin Explants}

Treatment A consisted of $3 \mathrm{mg} / \mathrm{L}$ of IAA and $4 \mathrm{mg} / \mathrm{L}$ of Kinatin hormones in 22 pt. MS medium containing leaves, leaves, and lateral buds, for which, the following were compared: 15 petri dishes had side-side finite samples, 15 petri dishes included side margins and 2 petri dishes consisted of finite meristem tip, which after 1 week of induction of microorganisms began to be treated with hormonal treatment. First, the leaves of 15 jams began to grow after 1 week possibly due to cell growth, and for other 3 jams, after another 7 weeks, hormonal effect increased. Size of the leaflet increased from about $8 \mathrm{~mm}$ to about $31 \mathrm{~mm}$," showing about $88 \%$ growth after 5 weeks.

\section{Effect of Hormone-B on Thin Explants}

Treatment B included $2 \mathrm{mg} / \mathrm{L}$ of BA and $4 \mathrm{mg} / \mathrm{L}$ of NAA hormones. In this treatment, there were 22 pituitary hormones including 15 petri dishes of Fine Bulb, 15 petri dishes of Tart, Side Scraps, and 2 tiny petri dishes of Tins, which were compared. First, in leaflets, cell growth was shown after 4 weeks, so that among 15 petri dishes, 13 petri dishes began to grow after 4 weeks, and size of the sample increased, possibly due to cell growth, and 2 pounds of it showed larger sizes after about 6 weeks of hormonal activity

\section{CONCLUSIONS}

Date palm tissue culture techniques have provided successful micropropagation of a large number of commercial varieties worldwide. Availability of Date palm vitro plants has had a tremendously positive effect on agricultural sector, mainly in oasis ecosystems. Normally, Date palm can be micropropagated through two main methods. One method is the embryogenesis technique in which somatic embryos are regenerated from embryogenic callus. Using this method, a large number of plants can be obtained in a short period. The second method is the organogenesis technique in which vegetative buds are regenerated from the cultured explants without passing through a callus stage. Since plantlets are obtained directly from mother tissue, typically they will be identical to the mother tree. Hence, this method is considered to be more secure, and risk of somaclonal variations can be easily avoided. Explants are commonly excised from offshoots shoot tips. This plant material is the most suitable for micropropagation of Date palm varieties. However, in case of some selected genotypes and rare cultivars, availability of offshoot is quite limited. The protocols described for Date palm micropropagation by organogenesis can be used at both research and commercial levels. Results of the study showed no difference in case of applying the propagation near and far from the end of the meristem region. In this study, the culture medium compared with the culture medium showed better results, indicating that difference was due to amount of auxin and cytokines hormones. Therefore, without using 2.4.of treatment $\mathrm{D}$, the callus could not be formed. Determining proper season for separation of offshoot from the mother plant was found to be important, and it was determined that end of summer and end of winter would be a more appropriate time for separation of the explants.

\section{CONFLICT OF INTEREST}

All authors declare do not have any conflicts of interest.

\section{REFERENCES}

Abahmane, L. (2011). Importance of inflorescence tissues in micropropagation of selected date palm (Phœnix dactylifera L.) genotypes. Paper presented at the Proceedings of the first scientific conference for the development of the palm and dates sector in Arab world, Saudi Arabia. 
Al-Khateeb, A. (2006). Role of cytokinin and auxin on the multiplication stage of date palm (Phoenix dactylifera L.) cv. Sukry. Biotechnology, 5(3), 349-352.

Al-Khayri, J. M. (2018). Somatic embryogenesis of date palm (Phoenix dactylifera L.) from shoot tip explants. In Step Wise Protocols for Somatic Embryogenesis of Important Woody Plants (pp. 231-244): Springer.

Al Kaabi, H., Rhiss, A., \& Hassan, M. (2001). Effect of auxins and cytokinins on the in vitro production of date palm bud generative tissues and on the number of differentiated buds. Paper presented at the Proceedings second international conference on date palm Al Ain, UAE.

Beauchesne, G., Zaid, A., \& Rhiss, A. (1986). Meristematic potentialities of bottom of young leaves to rapidly propagate date palm. Paper presented at the Proceedings second symposium on date palm. King Faisal University, Saudi Arabia.

Chao, C. T., \& Krueger, R. R. (2007). The date palm (Phoenix dactylifera L.): overview of biology, uses, and cultivation. HortScience, 42(5), 1077-1082.

Krueger, R. (2001). Date palm germplasm: overview and utilization in the USA. Paper presented at the Proc. International Conference on Date Palms.

McCubbin, M., Zaid, A., \& Van Stade, J. (2004). A southern African survey conducted for off-types on date palms produced using somatic embryogenesis. Emirates Journal of Food and Agriculture, 8-14.

Murashige, T., \& Skoog, F. (1962). A revised medium for rapid growth and bio assays with tobacco tissue cultures. Physiologia plantarum, 15(3), 473-497.

Saker, M., Bekheet, S., Taha, H., Fahmy, A., \& Moursy, H. (2000). Detection of somaclonal variations in tissue culture-derived date palm plants using isoenzyme analysis and RAPD fingerprints. Biologia Plantarum, 43(3), 347-351.

Sudhersan, C., AboEl-Nil, M., \& Al-Baiz, A. (1993). Occurrence of direct somatic embryogenesis on the sword leaf of in vitro plantlets of Phoenix dactylifera L. cultivar barhee. Current Science, 887-889. 